\title{
Lebiasina yepezi, a new Lebiasininae (Characiformes: Lebiasinidae) from the Serra Parima-Tapirapecó mountains
}

\author{
André L. Netto-Ferreira ${ }^{1}$, Osvaldo T. Oyakawa ${ }^{1}$, Jansen $_{\text {Zuanon }}^{2}$ and José C. Nolasco ${ }^{1}$
}

Lebiasina yepezi, a new Lebiasininae with a conspicuous color pattern, is described. The new species is endemic of the headwaters of the rio Negro, rio Branco, and rio Orinoco in the Serra Parima-Tapirapecó Mountains, at the border of Brazil and Venezuela. The new species is readily distinguished from all other Lebiasininae by the presence of four black longitudinal stripes on the trunk, and the triangular shaped dorsal surface of the mesethmoid, lacking lateral projections. The unusual color pattern is contrasted with those of other lebiasinin, as well as members of the pyrrhulinin genus Nannostomus. A close relationship between Lebiasina yepezi and the Gran Sabana (Venezuela) species is suggested based in color pattern features. The present contribution corresponds to a further refutation of the type locality of $L$. intermedia, as suggested on its description, since Lebiasinins, except L. bimaculata, L. boruca, and L. festae, do not occur in low land waters.

Lebiasina yepezi, um novo Lebiasininae com um conspícuo padrão de colorido, é descrito. A nova espécie é endêmica das cabeceiras do rio Negro, rio Branco e rio Orinoco, na Serra Parima-Tapirapecó, ao longo da fronteira entre Brasil e Venezuela. A nova espécie é prontamente diferenciada das demais espécies pela presença de quatro faixas longitudinais escuras ao longo do corpo, e a superfície dorsal do mesetmoide com o formato triangular, não apresentando projeções laterais. O padrão de colorido incomum é comparado com o dos demais Lebiasininae e também com o dos Pyrrhulininae do gênero Nannostomus. Uma próxima relação é proposta entre Lebiasina yepezi e as espécies da Gran Sabana (Venezuela) com base em caracteres de colorido. A presente contribuição corresponde a mais uma refutação da localidade-tipo de L. intermedia conforme sugerida na descrição daquela espécie, uma vez que os lebiasiníneos, com exceção de L. bimaculata, L. boruca e L. festae, não ocorrem em rios de terras baixas.

Key words: Distribution pattern, Gran Sabana, Guyana Shield, Ostariophysi, Systematics.

\section{Introduction}

The Lebiasinidae is a Neotropical characiform family consisting of seven genera distributed in two subfamilies: Lebiasininae (Lebiasina Valenciennes, plus Piabucina Valenciennes), and Pyrrhulininae (Pyrrhulina Valenciennes, Copeina Fowler, Copella Myers and Nannostomus Günther). The monotypic genus Derhamia Géry \& Zarske was originally assigned to the Lebiasininae (Géry \& Zarske, 2002), but it was not placed in either subfamilies by Weitzman \& Weitzman (2003), and it is currently considered an incertae sedis genus in the Lebiasinidae (Nelson, 2006). The species belonging to the family are small- to medium-sized fishes ranging from the miniature Nannostomus anduzei Fernandez \& Weitzman, about $1.6 \mathrm{~mm} \mathrm{SL}$, to species of Lebiasina, that reach up to $200.0-250.0 \mathrm{~mm} \mathrm{SL}$.

The greatest diversity of the family occurs in the Pyrrhulininae, which are distributed primarily in the Amazon and Orinoco basins, and coastal rivers of the Guyana Shield, occuring mainly in shallow waters of forest streams and small ponds along the lower parts of larger rivers. Pyrrhulina, the most widespread and speciose genus in the family, is the only one known for the Paraná-Paraguay system (including the rio Uruguay). Species of Lebiasininae, on the other hand, are usually found in the upper courses of streams with rocky or sandy bottoms and well oxygenated

${ }^{1}$ Universidade de São Paulo, Museu de Zoologia, P. O. Box 42494, 04218-970 São Paulo, Brazil. alnferreira@gmail.com; oyakawa@usp.br; cezarnolasco@yahoo.com.br

${ }^{2}$ Instituto Nacional de Pesquisas da Amazônia, Coordenação de Pesquisas em Biodiversidade, P. O. 478, 69060-001 Manaus, Brazil. zuanon@inpa.gov.br 
high waters in the rio Amazonas, rio Orinoco and coastal drainages on the Atlantic and Pacific slopes of Colombia, Costa Rica, Ecuador, Guyana, Panama, Peru, and Venezuela. The only exception would be Lebiasina intermedia Meinken, presumably from Santarém in the lower Amazon (Géry, 1977; Weitzman \& Weitzman, 2003).

Collections in the upper courses of the rio Negro, rio Branco, and rio Orinoco draining from the Serra ParimaTapirapecó, along the border of Brazil and Venezuela, yielded specimens of a conspicuously patterned new lebiasinin, which is described herein, and its relationships among other Lebiasininae are discussed. The new species is assigned to the genus Lebiasina following anterior studies questioning the validity of Piabucina (Eigenmann \& Allen, 1942; Weitzman, 1964; Machado-Allison, 1974; Dahl, 1971; Géry, 1977; Taphorn, 1992; Géry \& Zarske, 2002), or disregarding it (Ardila-Rodríguez, 1994, 1999, 2000, 2001, 2002, 2004, 2008a, $2008 \mathrm{~b}, 2009,2010)$, not withstanding the presence of an adipose fin in most species described.

\section{Material and Methods}

Counts and measurements follow Fink \& Weitzman (1974) and Menezes \& Weitzman (1990). All measurements were made point-to-point on the left side of the specimens whenever possible, with dial calipers with a precision of $0.1 \mathrm{~mm}$. Standard length is presented in $\mathrm{mm}$, all other measurements are presented as proportions of standard length (SL), except for subunits of head, which are presented as proportions of head length (HL). Meristic data are given in the description, followed by the frequency of each count in parenthesis, and an asterisk indicates the value of the holotype. Counts of teeth, vertebrae, supraneurals, and procurrent caudal-fin rays were taken only from cleared and double-stained paratypes (c\&s), prepared according to Taylor \& van Dyke (1985), or Xrayed specimens. Vertebrae of the Weberian apparatus were included as four elements in the precaudal counts, and the fused PU1+U1 of the caudal region as a single element in the caudal counts. Pattern of circuli and radii was observed on scales sampled from the region between the lateral line series and the insertion of the dorsal fin. Color pattern nomenclature follows Weitzman (1966). Institutional abbreviations follow Ferraris (2007), with the addition of CAR (Colección Carlos A. Ardila Rodríguez, Barranquilla, Atlantico, Colombia), IAvH-P (Instituto de Investigación de Recursos Biológicos Alexander von Humboldt, Colleción de Pecas, Villa de Leyva, Boyacá, Colombia), MAC-PAY (Ministerio de Agricultura y Cría, Instituto Nacional de Investigaciones Agricolas (INIA), Estación Experimental Amazonas, Puerto Ayacucho, Amazonas, Venezuela), UCR (Universidad de Costa Rica, Escuela de Biología, Museo de Zoologia, Departamento de Biología, Collección de Ictiología, San Jose, Costa Rica) and UF (University of Florida, Florida Museum of Natural History, Gainesville, Florida, USA.). Abbreviations used in the text are: FRO - frontal; LAT - lateral ethmoid; MES - mesethmoid; NAS - nasal; PRE - premaxillary.

\section{Results}

\section{Lebiasina yepezi, new species \\ Fig. 1}

Nannostomus or Pyrrhulina.-Géry, 1977: 588 [photography]. Lebiasina sp.-Géry \& Zarske, 2002: 44-45 [comparison with Derhamia hoffmannorum Géry \& Zarske].

Holotype. MNRJ 39067, 152.9 mm SL, Brazil, Amazonas State, upper rio Negro drainage, rio Marari, tributary of rio Padauari, at basecamp between 700 and 1000 m elev., upstream to Missão Marari of Ianomami Village, Serra Tapirapecó, 1¹2’26”N 6447'18’W, 12 Apr to 20 May 2004, U. Caramaschi \& D. F. Moraes.

Paratypes. MNRJ 38917, 24, 23.7-123.5 mm SL (4, 97.5-123.5 $\mathrm{mm} \mathrm{SL}$ ), same data as holotype. Brazil. Roraima State, rio Branco drainage: INPA 15091, 2, 21.8-40.5 mm SL, MZUSP 62918, 3, 31.9-81.5 mm SL, MZUSP 81128 ( $1 \mathrm{c} \& \mathrm{~s}, 42.8 \mathrm{~mm}$ SL) Igarapé das Irmãs, rio Parima, tributary of rio Branco, 21 Sep 1998, Oncocercosis Team. INPA $15742(1,88.2 \mathrm{~mm} \mathrm{SL})$, rio Parima, tributary of rio Branco, Xitei-Xidea, 2॰36'29'N 6352'18'W, 17 Apr 1979, U. Barbosa (Oncocercosis Team). INPA 15743 (9/18, 14.6-22.6 mm SL), MZUSP 62917 (8, 12.0-38.2 mm SL), Irmãs Xiteí, 9 Dec 1997, Oncocercosis Team. INPA 20518 (1, 93.6 mm SL), MZUSP $81129,1,90.2 \mathrm{~mm} \mathrm{SL}$, rio Mucajaí, tributary of rio Branco, Yanomami's indigenous area, Apr 2002, M. William. MPEG 1830, 1, $94.5 \mathrm{~mm}$ SL, Serra Parima, tributary of rio Uraricoera, $1200 \mathrm{~m}$ elev., Mar 1962, M. Hidasi [specimen examined by Géry, in Géry \& Zarske, 2002: 45]. MZUSP 62916, 1, $96.5 \mathrm{~mm}$ SL, rio Parima, tributary of rio Branco, Xitei-Xidea, 2॰36'29”'N 6352'18”W, 17 Apr 1979, U. Barbosa (Oncocercosis Team). USNM 306560, 3, 21.8-27.0 mm SL, río Parima, H. Axelrod, March 1963 [one specimen photographed and ilustrated in Géry, 1977: 588]. Venezuela. Amazonas State, rio Orinoco drainage: MAC-PAY 591 8, 37.1-134.9 mm SL (3, 90.6-134.9 mm SL), rio Niyayobä, Sierra Parima, $2^{\circ} 45^{\prime} \mathrm{N} 64^{\circ} 18^{\prime} \mathrm{W}, 17$ Oct 1982, J. Fernández. MAC-PAY 619, 3, 27.3-40.0 mm SL, Cañito Jopajewä, tributary of left margin of río Padamo, upstream of Coshilowäteri, tributary of right margin of rio Orinoco, $2^{\circ} 54^{\prime} \mathrm{N} 65^{\circ} 17^{\prime} \mathrm{W}, 22$ Oct 1982, J. Fernández. MBUCV 11000, 2, 114.3-145.8 mm SL (1, 145. 8 mm SL), Atabapo, Caño Herita, río Ocamo, tributary of right margin of upper rio Orinoco, $3^{\circ} 45^{\prime} \mathrm{N} 64^{\circ} 35^{\prime} \mathrm{W}$, Nov 1975, J. Lizot. MHNLS 4160, 1, $106.7 \mathrm{~mm}$ $\mathrm{SL}$, Mavaca, upper rio Orinoco, mouth of río Mavaca, $2^{\circ} 31^{\prime} \mathrm{N}$ $65^{\circ} 11^{\prime} \mathrm{W}$, Nov 1981, J. Finkers. MHNLS 797, 2, 40.8-83.8 mm SL, Venezuela, Amazonas, Raudal Culebra 336'N 6548'W, Dec 1951, A. Fernández-Yepez.

Diagnosis. Lebiasina yepezi is readily distinguished from all other members of Lebiasininae by the presence of a primary, secondary, tertiary, and intermediate stripes on the sides of the trunk (Fig. 1; vs. primary and secondary stripes present in most Lebiasininae, except: L. astrigata (Regan), L. aureogutatta (Fowler), L. chocoensis Ardila-Rodríguez and L. multimaculata Boulenger, which present only the secondary stripe), and dorsal surface of the mesethmoid triangular shaped (Fig. 2), without lateral projections (vs. mesethmoid T-shaped). Lebiasina yepezi further differs from its congeners (except L. taphorni Ardila-Rodríguez, L. unitaeniata (Günther), L. uruyensis Fernandez-Yepez, and $L$. 


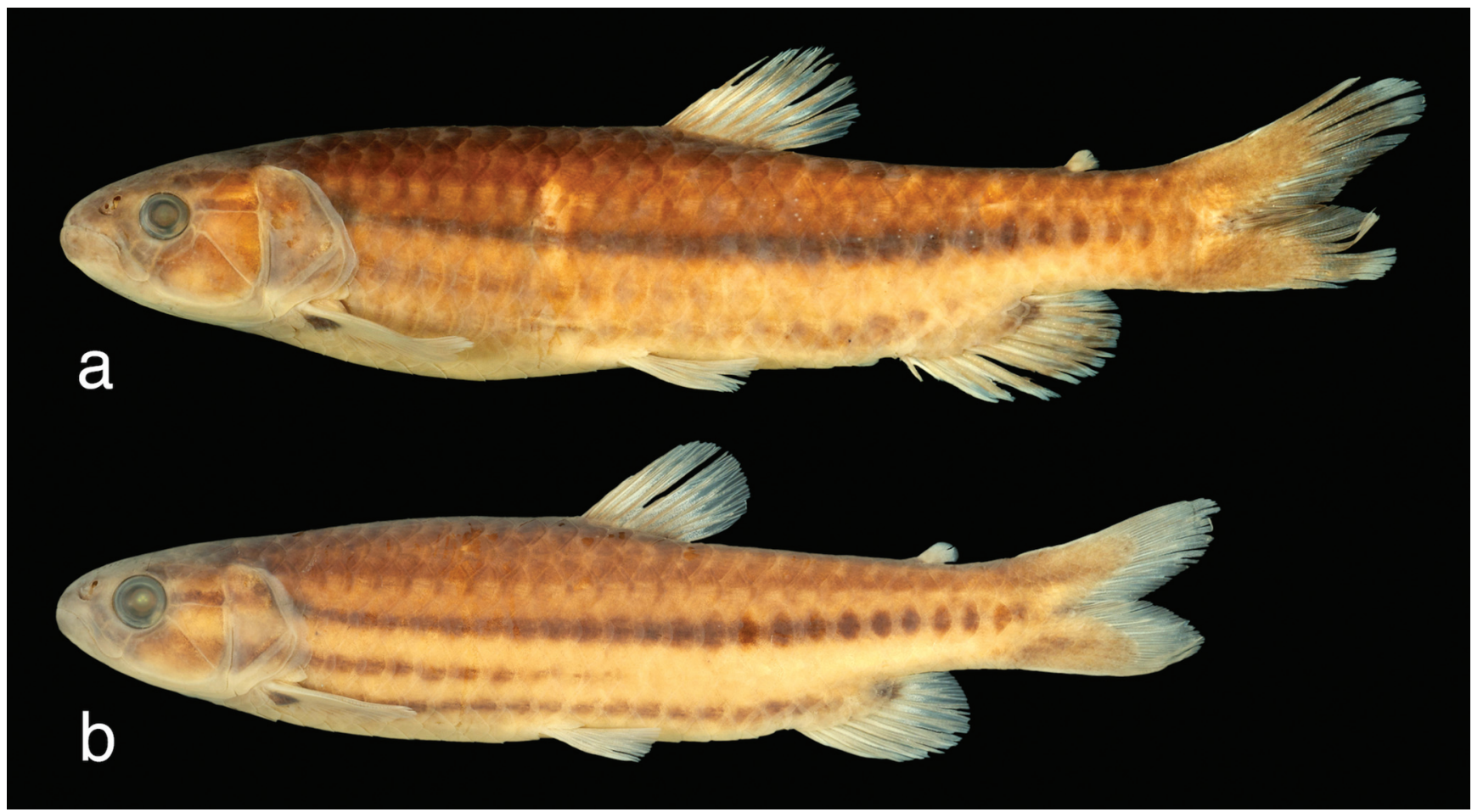

Fig. 1. Lebiasina yepezi: a) MNRJ 39067 holotype (152.9 mm SL), Brazil, Amazonas, rio Marari, tributary of rio Padauari, Serra Tapirapecó; b) MNRJ 38917, paratype (97.5 mm SL), same data as holotype.

yuruaniensis Ardila-Rodríguez) by the secondary stripe extending along scales of second and third longitudinal series (vs. stripe extending along scales of first and second longitudinal series), and caudal-fin blotch restricted to the caudal-fin median rays ( $v s$. anterior margin of candal-fin blotch extending onto caudal peduncle). The new species also differ from its closest geographical relatives, $L$. yepezi differs from L. taphorni Ardila-Rodríguez, L. unitaeniata (Günther), L. uruyensis, and L. yuruaniensis Ardila-Rodríguez by the extent of the intermediate stripe (from infraorbitals to anal-fin origin; $v s$. intermediate stripe restricted to infraorbitals 2 to 4 ).

Description. Morphometric data of Lebiasina yepezi are presented in Table 1. Body compressed and elongate. Dorsal profile of body distinctly convex from upper lip to vertical through nares, becoming slightly convex from that point to vertical through pectoral-fin origin, then nearly straight from latter to dorsal-fin origin; and slightly concave from that point to dorsal caudal-fin procurrent rays. Ventral profile of head and trunk convex from lower lip to pelvic-fin origin; straight from that point to anal-fin origin, convex at anal fin base, and concave from anal fin terminus to caudal-fin procurrent rays.

Mouth terminal. Premaxillary with single row of 9(1) or 11(1) tricuspid teeth decreasing in size posteriorly. Posterior tip of maxillary reaching distinctly beyond vertical through anterior margin of orbit. Maxillary with 5(1) or 7(1) tricuspid teeth. Dentary with two series of teeth. Outer series with 12(1) or 18(1) pedunculate tricuspid teeth with central cusp distinctly larger, teeth gradually decreasing in size posteriorly. Inner series with several minute conical teeth extending from the symphysis to coronoid process. Branchiostegal rays 4, 3 articulating with anterior-ceratohyal, and one with posteriorceratohyal.

Scales cycloid, circuli restricted to posterior border of scales, several radii (approx. 25) converging to center of scales and strongly anastomosed in the center, forming several cells. Lateral line longitudinal series with 26(1), 27(5), 28*(4), or 29(1) scales, of which only $3(3), 4(1), 5^{*}(9)$, or 6(1) are perforated. Longitudinal rows of scales between dorsal and pelvic fins 7. Predorsal scales 12(7) or 13*(7). First longitudinal row of scales usually reaching vertical through dorsal-fin terminus, but may extend beyond that point by one or two scales. Circumpeduncular scales 12 .

Pectoral fin with i,13(1), 14(4), 15*(5), or 16(2) rays. Pelvic fin i, $7^{*}$. Supraneurals $10(8)$, anterior to neural spine of centra 5 to $14(8)$. Dorsal fin ii, $8^{*}(8)$ or $9(4)$ rays. First dorsal-fin pterygiophore inserted posterior to neural spine of centrum 14(8). Distal margin of extended dorsal fin rounded. Dorsalfin origin closer to caudal-fin origin than to tip of snout. Base of last dorsal-fin ray anterior to vertical through analfin origin. Anal fin iii, $8^{*}(9)$ or 11(1), last ray adnate. Distal border of extended anal fin rounded. First anal-fin pterygiophore inserted posterior to hemal spine of centrum 24(8). Adipose fin present. Caudal fin furcate, with upper lobe distinctly longer than lower lobe; both lobes rounded. Principal caudal-fin rays i, $9 / 8$,i. Dorsal procurrent rays $9(2)$; 


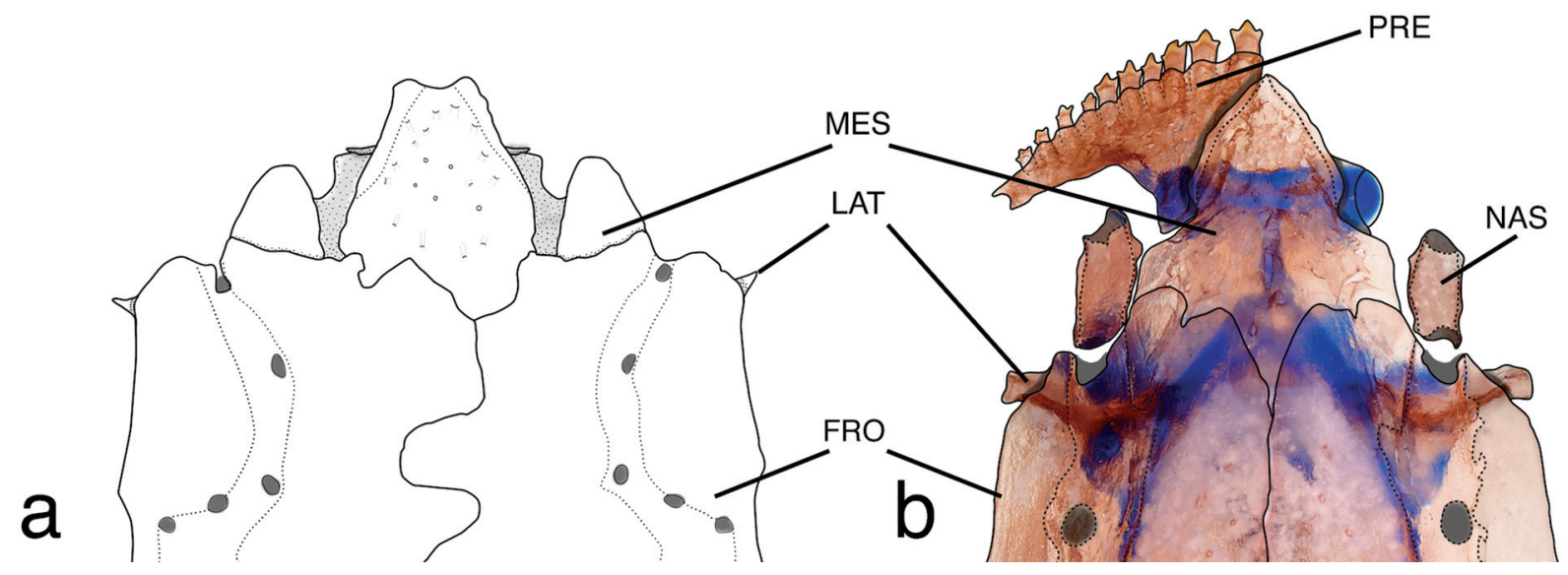

Fig. 2. Anterior portion of the skull in dorsal view of: a) Lebiasina astrigata (MEPN 4418, $94.5 \mathrm{~mm} \mathrm{SL}$ ); b) Lebiasina yepezi. (MZUSP 81128, $42.8 \mathrm{~mm} \mathrm{SL}$ ), showing the usual T-shaped mesethmoid of Lebiasininae and the absence of lateral projections, respectively (FRO - frontal; LAT - lateral ethmoid; MES - mesethmoid; NAS - nasal; PRE - premaxillary).

ventral procurrent rays 8(1) or 9(1). Precaudal vertebrae 23(2); caudal vertebrae 19(2).

Color in alcohol. Background color yellowish. Head densely pigmented from upper lip to origin of scales on the midposterior portion of parietals. Dark brown pigmentation extending from that point to caudal-fin insertion, through middorsal series of scales and immediately bordering scale rows. Infraorbital bones and opercular series with yellowish background color, with dark portions where primary, secondary and intermediate stripes extend across. Lower lip dark, densely pigmented. Ventral portion of head with minute scattered chromatophores.

Trunk dark dorsally, becoming lighter ventrally from third longitudinal series of scales. Abdominal area yellowish, lacking pigmentation between the isthmus and anal-fin origin. Mid-dorsal series with a black longitudinal stripe from back of head to dorsal-fin origin. Humeral blotch inconspicuous, round, overlapped by primary stripe. Four dark longitudinal stripes on the trunk. Primary stripe conspicuous, originating posterior to eye, extending across infraorbitals four and five, opercle and along trunk, to terminate at rear of caudal peduncle. Stripe subdivided starting at vertical through dorsal-fin terminus, into 10-12 small round blotches, overlying scales of fourth longitudinal series. Secondary stripe inconspicuous, extending from supracleithrum to middle rays of upper caudalfin lobe, over second and third longitudinal series of scales. Conspicuous intermediate stripe usually extending from mouth to vertical through anal-fin origin, onto scales of fifth longitudinal series, between primary and tertiary stripes. Tertiary stripe densely pigmented, except at proximal portion of caudal peduncle, extending from pectoral-fin origin to middle portion of caudal-fin lower lobe, onto scales of sixth longitudinal series. Caudal-fin blotch diffuse and rounded in juvenile specimens, located at basal portion of five median caudal-fin rays; caudal-fin blotch inconspicuous or absent in specimens longer than $123.0 \mathrm{~mm} \mathrm{SL}$, in which it may be represented by patches of chromatophores. Anterior border of caudal-fin blotch not extending onto caudal peduncle. Pelvic and dorsal fins hyaline, base of pectoral-fin rays densely pigmented, forming a round dark blotch. Anal fin lightly pigmented, grayish, with distal border hyaline. Base of last two anal-fin branched rays densely pigmented, forming an oblong dark blotch. Caudal-fin rays densely pigmented.

Table 1. Morphometric and meristic data for Lebiasina yepezi. SD - standard deviation.

\begin{tabular}{lccccc}
\hline & Holotype & $\mathrm{n}$ & Range & Mean SD \\
\hline Standard length & 152.9 & 22 & $12.0-152.9$ & 80.7 & - \\
& 20.9 & 12 & $18.6-23.2$ & 21.3 & 1.4 \\
Depth at dorsal-fin origin & 73.5 & 12 & $73.5-79.3$ & 76.0 & 1.8 \\
Snout to anal-fin origin & 50.2 & 12 & $49.8-53.9$ & 51.8 & 1.4 \\
Snout to pelvic-fin origin & 53.5 & 12 & $53.5-57.0$ & 54.8 & 1.2 \\
Snout to dorsal-fin origin & 47.7 & 12 & $45.0-48.3$ & 46.5 & 1.1 \\
Dorsal-fin origin to caudal-fin base & 18.5 & 11 & $18.2-19.6$ & 18.9 & 0.5 \\
Dorsal-fin length & 9.9 & 12 & $9.0-10.9$ & 9.9 & 0.5 \\
Dorsal-fin base & 12.5 & 12 & $11.5-13.4$ & 12.5 & 0.7 \\
Adipose-fin to caudal peduncle & 14.8 & 12 & $14.2-16.3$ & 15.2 & 0.6 \\
Caudal-peduncle Length & 9.9 & 12 & $8.7-10.6$ & 9.5 & 0.7 \\
Caudal-peduncle Depth & 19.9 & 12 & $18.1-21.3$ & 19.7 & 1.0 \\
Anal-fin length & 10.7 & 12 & $9.3-12.3$ & 10.5 & 1.1 \\
Anal-fin base & 24.6 & 12 & $22.3-25.9$ & 24.8 & 1.1 \\
Pelvic- to anal-fin origin & 12.2 & 12 & $12.0-15.1$ & 12.9 & 0.9 \\
Pelvic-fin length & 28.5 & 12 & $27.9-31.3$ & 29.5 & 1.1 \\
Pectoral to pelvic-fin origin & 15.9 & 12 & $15.5-17.7$ & 16.4 & 0.7 \\
Pectoral-fin length & 21.2 & 12 & $21.2-25.9$ & 23.1 & 1.4 \\
Snout to pectoral-fin origin & 23.6 & 12 & $23.4-26.6$ & 25.2 & 1.0 \\
Bony head length & 13.0 & 12 & $12.7-14.6$ & 13.4 & 0.6 \\
& 4.5 & 12 & $4.5-6.3$ & 5.4 & 0.6 \\
Head width & 6.7 & 12 & $6.7-8.1$ & 7.6 & 0.4 \\
Horizontal eye diameter & 9.1 & 12 & $9.1-9.7$ & 9.3 & 0.2 \\
Distance snout tip to eye & 10.3 & 12 & $10.1-12.2$ & 11.2 & 0.7 \\
Interorbital distance & 5.1 & 12 & $5.1-10.3$ & 7.0 & 2.1 \\
Lower jaw length & & & & \\
Upper jaw length & Percentage of HL & & & &
\end{tabular}


Sexual Dimorphism. Mature males of Lebiasina yepezi present the most common pattern of sex dimorphism among species of the genus: in which the anal-fin rays and anal-fin base are distinctly longer and thicker than females (Fig. 3); hypertrophy of the inclinator muscles and the spiniform processes in which the muscles attach to the first lepidotrichia; scales of the fifth longitudinal series along the base of the anal fin modified (covered by a thin layer of a spongeous, apparently glandular, tissue); and breeding tubercles present on pectoral-, pelvic- and anal-fins rays, as well as on scales and sides of the head.

Distribution. Specimens of Lebiasina yepezi are known from rio Parima (rio Mucajaí system) and rio Uraricoera in the rio Branco drainage, rio Amazonas system, Roraima State, Brazil, the rio Marari (rio Padauari system) in the rio Negro drainage, rio Amazonas system, Amazonas State, Brazil, and the upper rio Orinoco drainage, upstream of La Esmeralda, Amazonas State, Venezuela (Fig. 4).

Etymology. The specific name honors Agustín Fernández Yépez, first collector of the new species described herein.

Ecological notes. Lebiasina yepezi inhabits small and shaded forest streams, with fast-flowing clear water and a substrate consisting mainly of rocks and sand.

\section{Discussion}

In his study of the fish fauna near the río Yaracuy in Venezuela, Fernández-Yépez (1972: 13) mentions in passing a species yet to be described from the upper course of the Orinoco. Given that author had collected specimens of Lebiasina yepezi in 1951 (MHNLS 797), it is likely that he was referring to this species in his comment. Géry (1977: 588) was the first to depict the new species in a photo by Axelrod of a juvenile specimen collected at the Parima mountains in northern Brazil, which is currently cataloged as USNM 306560. In the occasion, Géry listed it as an unidentified characiform, "possibly near Nannostomus or Pyrrhulina". Subsequently, Géry \& Zarske (2002: 44-45) proposed a possible relationship between this species and Derhamia hoffmannorum, based on their conception of the relationships of the lebiasinid genera, but the authors did not provide evidence to such a hypothesis. In two phylogenetic studies based on morphologic data of the family Lebiasinidae, Netto-Ferreira $(2006,2010)$ refuted this hypothesis, proposing L. yepezi as being more closely related to the Lebiasinins from the Guyana Shield than Derhamia. Such close relationship between Lebiasina yepezi and its congeners from the Gran Sabana, Venezuela, L. taphorni, L. unitaeniata, L. uruyensis, and $L$. yuruaniensis (fig. 4) is supported by: first longitudinal series of scales short, ending near the dorsal-fin terminus; posteriorly displaced caudal blotch, not located on the caudal peduncle; secondary stripe passing onto the scales of the second and third longitudinal rows of scales; and the presence

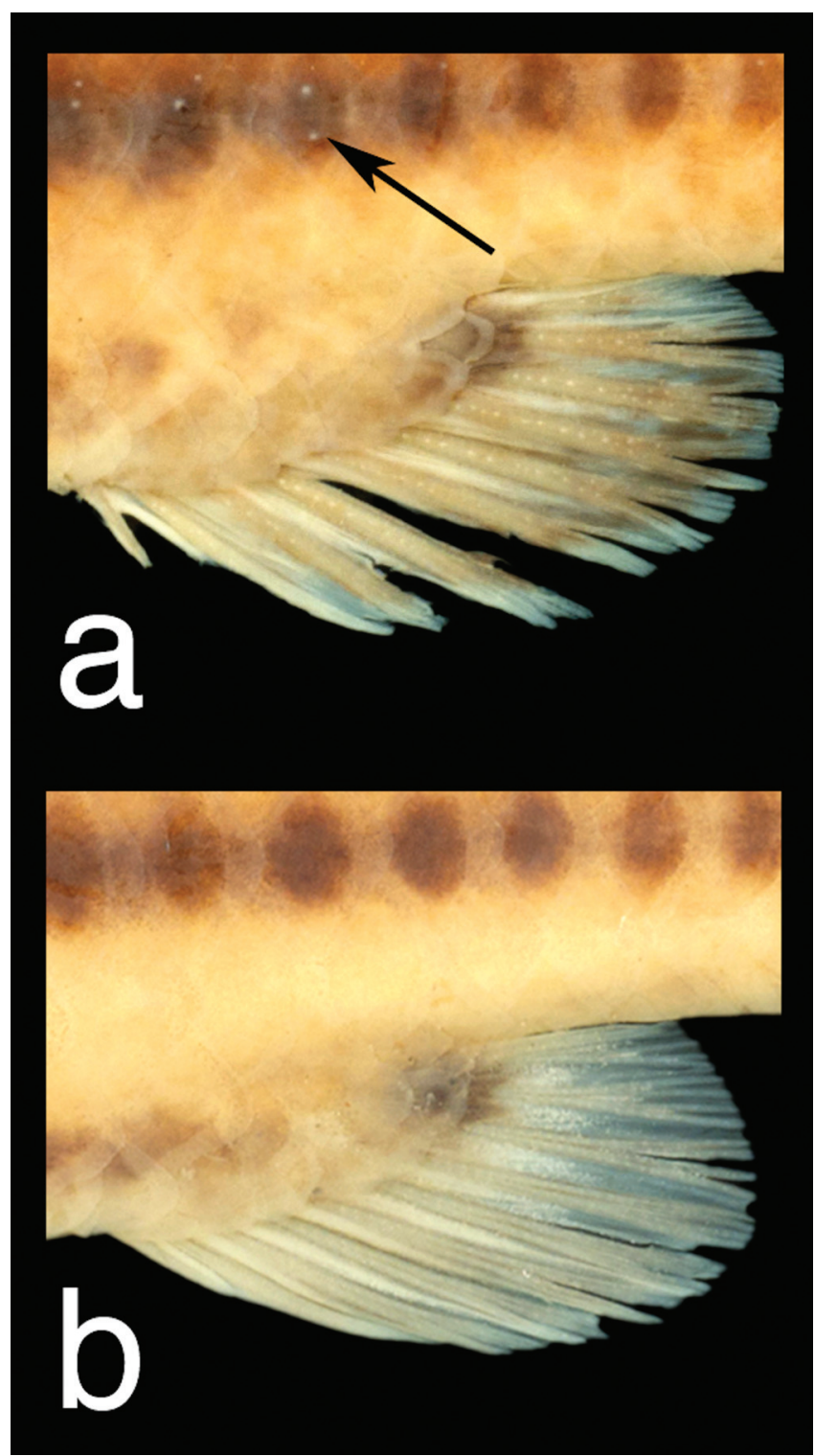

Fig. 3. Anal-fin of Lebiasina yepezi evidencing the sexual dimorphism: a) Male (MNRJ 39067 - holotype) $152.9 \mathrm{~mm} \mathrm{SL}$; b) female (MNRJ 38917 - paratype) $97.5 \mathrm{~mm} \mathrm{SL}$. Arrow indicates breeding tubercles on the scales.

of the intermediate stripe, passing at least onto third infraorbital, usually represented by a horizontally elongate blotch (which in few specimens of L. uruyensis may form an inconspicuous stripe, passing onto the scales of the fifth longitudinal series in a way similar to that in L. yepezi).

The presence of multiple dark longitudinal stripes along the body is an unusual color pattern among the Lebiasininae, albeit common among species of the Pyrrhulininae genus Nannostomus (three stripes present in N. limatus Weitzman, N. marginatus Eigenmann, N. marilynae Weitzman \& Cobb, N. minimus Eigenmann, N. mortenthaleri Paepke \& Arendt, $N$. rubrocaudatus Zarske, and N. trifasciatus Steindachner; 


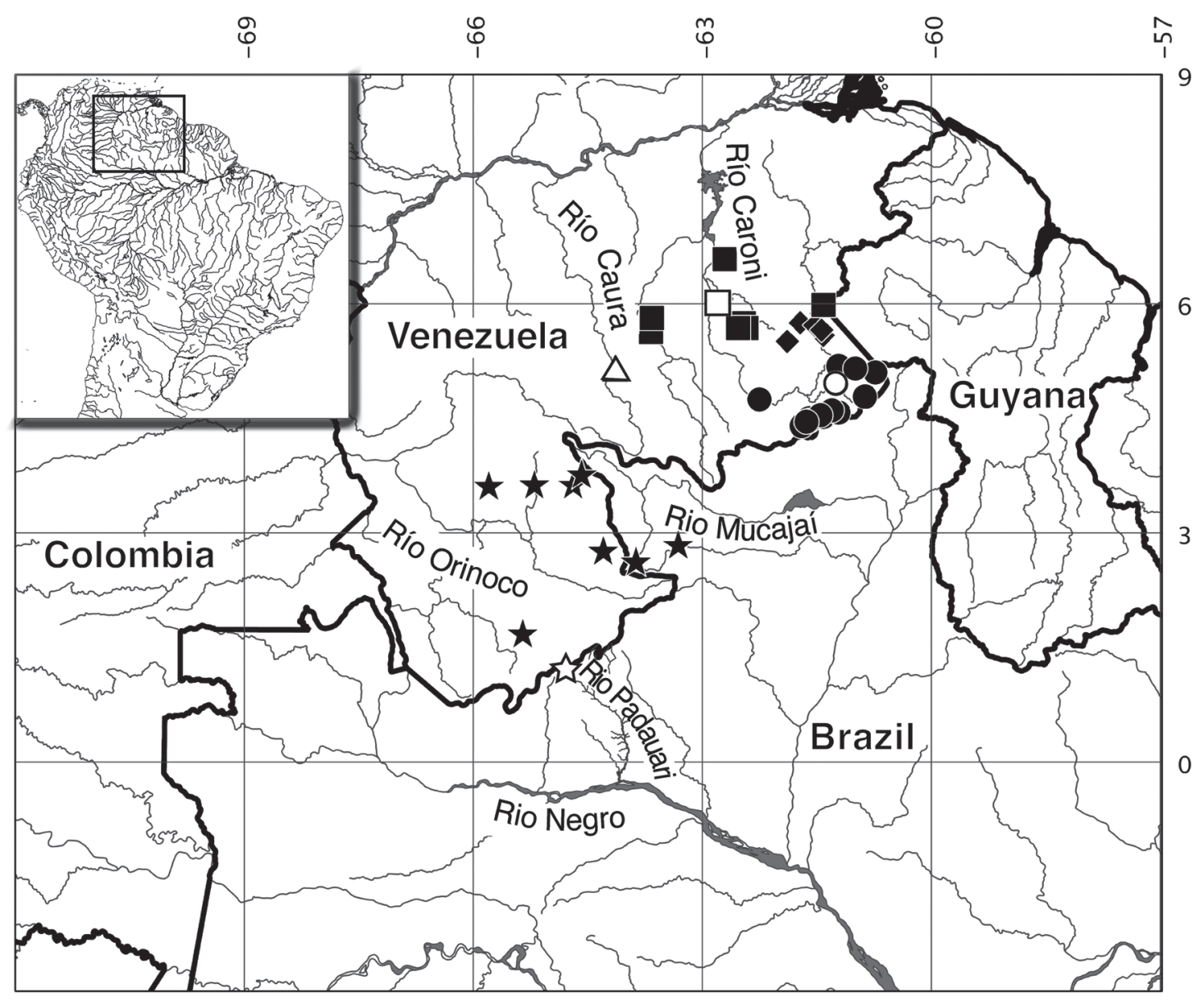

Fig. 4. Map of northern portion of South America with the distribution of Guyana Shield species of Lebiasininae: Lebiasina yepezi (stars), L. unitaeniata (diamonds), L. uruyensis (squares), L. taphorni (triangle) and L. yuruaniensis (circles). White polygons represent type-localities.

four stripes in $N$. britskii Weitzman and $N$. eques Steindachner). Young specimens of Lebiasina yepezi can be distinguished from these species of Nannostomus with a somewhat comparable color pattern by the broader and slightly upturned mouth and the presence of tricuspidate teeth (vs. a narrow terminal mouth with spatulate multicuspid teeth in Nannostomus).

Lebiasina yepezi represents an additional species inhabiting both the rio Negro and rio Orinoco drainages. The continuous discovery of new species restricted to the headwaters of rivers draining from the Guyana Shield (Fernández-Yépez, 1967; Ardila-Rodríguez, 1999, 2000, 2004) suggests that the diversity of the Lebiasininae in that area still needs further investigation. Ongoing revisionary studies conducted by the senior author revealed three new lebiasinins occurring in the headwaters of the rio Mazaruni and the rio Potaro (a drainage exhaustively sampled by Eigenmann in the early $20^{\text {th }}$ century) in the Guyana Shield.

Additionally, three new species have also been discovered in the headwaters of rio Xingu and rio Tapajós, in the Brazilian Shield, an area where lebiasinins were not expected to occur. The apparent peripheric distribution of these species in the upper portions of the rio Amazonas and the rio Orinoco systems represent further evidence that, with exception of Lebiasina bimaculata, L. boruca, and L. festae, species of Lebiasininae do not inhabit low land waters, living exclusively in fast flowing clear headwaters. Therefore, Meinken's suggestion that the type locality of $L$. intermedia, "near Santarém" is most likely inaccurate as suggested by Géry (1977) and Weitzman \& Weitzman (2003). So far, any recent collection yielded specimens comparable with that described by Meinken, and it is likely that specimens of L. intermedia are still awaiting to be rediscovered in either Guyana or Brazilian Shields.

Comparative Material. Lebiasina astrigata: Colombia. CAR 187 (11, 70.6-138.4 mm SL), Nariño, creek tributary of Quebrada Indó, Quebrada Indún, 0142'00”N 78¹9'00"W. Ecuador. MEPN 4109 (4, 93.2-101.2 mm SL), Carchi, Quebrada Pailón, 00²8'59'N $77^{\circ} 55^{\prime} 01^{\prime \prime}$ 'W. MEPN 4130 (1, 56.9 mm SL), Carchi, Quebrada Negra, sítio San Marcos, $01^{\circ} 03$ '25'N 78¹8'14”W. BMNH 1898.4.28:1646 Syntypes (3, 67.5-69.5 mm SL), Carchi/Imbabura, Paramba. BMNH1901.3.29:71 Syntype (1, 130.5 mm SL), Esmeraldas, San Javier, río Cachaví. BMNH 1902.7.29:59 Syntype (1,158.8 mm $\mathrm{SL})$, Esmeraldas, río Sapayo. MCZ 54125 (3, 112.5-141.9 mm SL), 
Esmeraldas, rios Cayapas, Hoja Blanca and San Miguel [de Cayapas], río Santiago drainage, $78^{\circ} 55^{\prime} \mathrm{W} 00^{\circ} 46^{\prime} \mathrm{N}$. MEPN 4418 ( 2 c\&s, 94.5103.6 mm SL; 21, 29.2-105.4 mm SL), Esmeraldas, creek of rio Mira, $80 \mathrm{~m}$ downstream of Casa Manuel Puy, $01^{\circ} 13^{\prime} \mathrm{N} 78^{\circ} 36^{\prime} \mathrm{W}$. Lebiasina aureogutatta, Ecuador. ANSP 39103 Holotype (1, 127.6 $\mathrm{mm} \mathrm{SL}$ ), Guayas, tributary of río Chimbo, near Bucay, $02^{\circ} 10^{\prime} 00^{\prime \prime S}$ 7906'00”W. ANSP 45474 (1, 80.5 mm SL), Mina [Guayas, río Minas, río Guayas drainage, $02^{\circ} 41^{\prime} 26^{\prime \prime S} 79^{\circ} 38^{\prime} 16^{\prime \prime W}$. MCNG 19378 (1, 104.0 mm SL), Bolívar, río Chimbo, 205'56”S 7941'47’W. MEPN 6232 (5, 79.4- 112.9 mm SL), Bolivar, río Chanquil, near San José del Tambo. FMNH 93122 (19/80, 38.1-141.6 mm SL), Los Rios, small pool at Centro Científico río Palenque, $00^{\circ} 35^{\prime} 00^{\prime \prime} \mathrm{S}$ 79²2'00'W. MCZ 48728 (1, $57.1 \mathrm{~mm} \mathrm{SL})$, Pichincha, arroyo Guanecilla, río Blanco drainage, $00^{\circ} 13$ 'S 7909'W. MEPN 9469 (4, 73.6-142.9 mm SL), Pichincha, río Pachijal, affluent of río Guayllabamba, río Esmeraldas drainage, $0^{\circ} 12$ '10”N 7843'16”W. CAS uncat. (ex-IU 13534) (32, 43.3-90.7 mm SL), Pichincha, río Mindo [río Guayllabamba drainage], in a farm west of Quito, $00^{\circ} 05^{\prime} \mathrm{S}$ 78³5'W. Lebiasina bimaculata, Peru. ROM 52209 (26, 23.0-61.4 $\mathrm{mm}$ SL), Ancash, río Sechin, $4 \mathrm{~km}$ east of Buena Vista, near Panamericana Highway, 9²9'03"'S 78 ${ }^{\circ} 18$ '15"W. MUSM 5188 (4, 35.2-46.1), Cajamarca, San Ignacio, tributary of río Tabaconas, 0507'22”'S 7857'10”W. MZUSP 80083 (13, 34.0-47.9 mm SL), Cajamarca, Magdalena, río Jequetepeque, $7^{\circ} 15^{\prime} 30^{\prime}$ 'S 78 $38^{\prime} 47^{\prime}$ 'W. LIRP 4379 (4, 43.0-49.1 mm SL), Cajamarca, Magdalena, río Jequetepeque, $07^{\circ} 13^{\prime} 35^{\prime}$ 'S 7850'00'W. MCZ 54123 (1, $121.3 \mathrm{~mm}$ $\mathrm{SL})$, Lima, Chosica, río Rimac, $40 \mathrm{Km}$ southeastern from Lima, 11'56'30"S 7641'54'W. MNHN 141 Holotype (1, 76.0 mm SL), [Lima] río Rimac, near Lima, CAS 70420 (ex-IU 17587) (12, 34.4$162.0 \mathrm{~mm} \mathrm{SL}$ ), La Libertad, laguna Hornito, mouth of río Jequetepeque, $07^{\circ} 19^{\prime} 41^{\prime \prime}$ S 79³5'26”'W. Lebiasina boruca, Costa Rica. UCR 42-2 Paratypes (4, 114.2-121.4 mm SL), Alajuela, between La Marina and Águas Zarcas, $10^{\circ} 18^{\prime} \mathrm{N} 84^{\circ} 18^{\prime} \mathrm{W}$. ANSP 140656 (3, 68.2-78.7 mm SL), Puntarenas, creek near the road Palmar Norte- Puerto Cortes, 900’N 8330'W. LACM 2926 Paratype (1, 117.4 mm SL), Puntarenas, río Sonador, $570 \mathrm{~m}$ elev., 09¹4'47.7’'N 83²9'37.4'W. LACM 4743 Paratypes (5/6, 17.6-24.4 mm SL), Puntarenas, río Convento, 09¹4'19.3”N 83²9'19.1”W. LACM 9239 Holotype $(1,117.4 \mathrm{~mm} \mathrm{SL})$, Puntarenas, creek on the road to Golfito, Panamericana Highway, 08³7'11.23'N 8303'36.7'W. UF 19537 (1, 97.0 mm SL), San Jose, río San Isidro, San Isidro del General, Panamericana Highway. USNM 194229 (2, 55.5-107.6 $\mathrm{mm}$ SL), San Jose, río Unión near San Isidro, Panamericana Highway, 09²2'00”N 8341'17.2”W. Panama. ANSP 151023 (4, 77.9-92.7 $\mathrm{mm}$ SL), Chiriqui, creek $29 \mathrm{~km}$ south of Interamericana Highway, 08¹9'9.6”N, 8249'34.0”W. Lebiasina chocoensis, Colombia. ANSP 84172 (3, 64.0-112.0 mm SL), Chocó, Nuquí, upper río Jurubidá, aprox. $05^{\circ} 50^{\prime} \mathrm{N} 77^{\circ} 17^{\prime} \mathrm{W}$, north of Baudó and east of Quibdó; CAR 185 Paratypes (5/6, 108.0-148.6 mm SL), Chocó, Quibdó, Quebrada affluent of río Tutunendo, $05^{\circ} 46^{\prime} 56^{\prime} \mathrm{N}$ 76³4'18'W. CAR 186 (12/18, 18.9-136.8 mm SL), Chocó, Quibdó, Quebrada affluent of río Tutunendo, $05^{\circ} 46^{\prime} 56^{\prime}$ "N 76 34 ' $18^{\prime}$ 'W. CAR 315 (ex-CAR 185) Holotype (1, 108.0 mm SL), Chocó, Quibdó, Quebrada affluent of río Tutunendo, $05^{\circ} 46^{\prime} 56^{\prime \prime} \mathrm{N} 76^{\circ} 34^{\prime} 18^{\prime \prime} \mathrm{W}$. IAvH-P 573 (1, $76.8 \mathrm{~mm} \mathrm{SL})$, Chocó, río del Valle, 0606’37"N $77^{\circ} 24^{\prime} 45^{\prime}$ 'W, coastal drainage. ICNMHN 6872 Paratypes [not ICN 6772 as in Ardila-Rodríguez, 2010:05] (4, 65.6-107.1 mm SL), Chocó, Quibdó, Quebrada affluent of río Tutunendo, $05^{\circ} 46^{\prime} 56^{\prime \prime} \mathrm{N}$ 76³4'18'W. Lebiasina colombia, Colombia. CAR 190 Holotype (1, 131.6 mm SL), Córdoba, Tierralta, Quebrada el Higuerón, tributary of río Sinú, $08^{\circ} 11$ '38.6”N 7604'44.0"W. CAR 191 Paratypes (4/8, 100.5-166.2 mm SL), same data as holotype. CAR
192 Paratypes (10, 59.7-138.0 mm SL), same data as holotype. CAR 408 (5/7, 94,4-125.6 mm SL), Córdoba, Quebrada la Corobá, tributary of Quebrada Tuis Tuis, $08^{\circ} 03^{\prime} 38.83^{\prime} \mathrm{N} 76^{\circ} 07^{\prime} 53.7^{\prime}$ 'W. CAR 447 (1, 94,4-125.6 mm SL), Córdoba, río Manso, PNN [Parque Nacional Natural] Paramillo, 07³9'60'N 76¹0'00”'W. CAS uncat. (ex-SU 49514) (1, 59.8 mm SL), Córdoba, Crucito, upper río Sinú, $09^{\circ} 24^{\prime} \mathrm{N} 75^{\circ} 49^{\prime} \mathrm{W}$. ICNMHN 5314 Paratype (1, $\left.71.44 \mathrm{~mm} \mathrm{SL}\right)$, Córdoba, río Sinú, near mouth to río Urrá, 0756'21.4”N 76¹1'58.1"W. ICNMHN 10692 (3, 79.4-115.4 mm SL), Córdoba, Tierralta, Quebrada el Higuerón, tributary of río Sinú, $08^{\circ} 11$ '38.6”N 7604'44.0'W. Lebiasina elongata, Ecuador. BMNH 1880.12.8.123 Lectotype (1, $101.8 \mathrm{~mm} \mathrm{SL})$, Pastaza, Canelos [upper río Bobonaza, left bank tributary of río Pastaza, río Marañon drainage, 01'35'22.0'S 7744'47.7'W. BMNH 1880.12.8.124 Paralectotype $(1,111.9 \mathrm{~mm}$ SL), same data as lectotype. MEPN $9131(5,83.2-$ $137.1 \mathrm{~mm}$ SL), Napo, río Pucuno, $300 \mathrm{~m}$ elev., 0103'56”S 77³8'16”W. USNM 164062 (7, 67.8-108.7 mm SL), Napo río Misahuallí, in Misahuallí $01^{\circ} 02$ '00.3”S 77³9'52.0”W. USNM 258065 (3, 44.1-74.7 mm SL), Napo, Quebrada in Sarayacu, tributary of río Misahuallí, río Napo drainage, in the highway BaezaArchidona, 1500 m elev., 00³9'18.9"S 7746'55.2'W. Colombia. CAR 136 (9/10, 22.7-66.2 mm SL), Caquetá, Quebrada Pabarpaco, upper río Caquetá, $01^{\circ} 04$ '54”N 7546'19'W. CAR 149 (2, 72.6$117.7 \mathrm{~mm} \mathrm{SL})$, Putumayo, Orito, vereda el Líbano, upper río Putumayo, 775-850 m elev. , 0040'53.8”N 7702'07.2”W. Peru. MUSM 5666 (1, $118.2 \mathrm{~mm}$ SL), Amazonas, arroyo Condorcangui, río Comainas, downstream of PV22 basecamp, $04^{\circ} 01^{\prime} 00.4$ "S 78²4'7.9'W. Lebiasina erythrinoides, Colombia. IAvH-P 9209 $(1,27.5 \mathrm{~mm} \mathrm{SL})$, Casanare, Pore, río Pore, $100 \mathrm{~m}$ bellow the road Yopal-Pore, $360 \mathrm{~m}$ elev., $05^{\circ} 43^{\prime} 45^{\prime \prime} \mathrm{N} 72^{\circ} 00^{\prime} 04$ 'W. IAvH-P 9210 (3, 60.5-94.8 mm SL), Casanare, Yopal, Quebrada Agua Blanca, tributary of río Cravo Sur, $760 \mathrm{~m}$ elev., 05²8'17.6”N 72²7'04.5”'W. CAR 205 (3, 33.9-69.5 mm SL), Norte de Santander, Pamplonita, Quebrada Mutiscua 7०17'59.4”N 72॰44'58.6”W. Venezuela. MNHN 4614 Syntypes (2, 123.7-144.7 mm SL), [Zulia] Lake Maracaibo. MNRJ 14230 (7, 53.4-82.6 mm SL), Barinas, Quebrada tributary of río Qui, $2 \mathrm{~km}$ north of higway and upstream of Fazenda Qui, 8०04'30'N 7056'55'W. MBUCV uncat (1, 46.9 mm SL), Barinas, río Masparro, between Boconoito and Barrancas, in front of Masparro, 08 47'40.7'N 7004'46.8'W. INHS 28919 (3, 64.5$127.3 \mathrm{~mm} \mathrm{SL}$ ), Carabobo, río Capa, río Urama basin, Caribbean sea drainage, $10^{\circ} 18^{\prime} 44.1$ 'N $68^{\circ} 17^{\prime} 00^{\prime \prime W}$. CAR 450 (ex-MHNLS 4336) (2, 130.0-153.4 mm SL), Yaracuy, Quebrada el Charcal, Finca Jaguar, Quebrada el Charal 10`31'22.8'N 6857'45.9'W. INHS 34955 (2, 163.2-192.9 mm SL), Trujillo, creek tributary of Montatán, 09¹2'46”'N 7040’08”'W. UF 25457 (3, 71.7-129.2 mm SL), Zulia, Heras, bridge of río Frio, Panamerican highway, $08^{\circ} 58^{\prime} 08.0^{\prime \prime} \mathrm{N}$ 71'24'58.4'W. Lebiasina festae, Colombia. CAR 143 (8, 80.9130.0), Antioquia, Vigia del Fuerte, $06^{\circ} 35^{\prime} 48.8^{\prime}{ }^{\circ} \mathrm{N} 76^{\circ} 53^{\prime} 10.0$ ' W. ANSP 84264 (2, 95.7-110.5 mm SL), Chocó, río Dagua, Buenaventura, 0325'44.9'N 77³'10.4'W. CAR 137 (8/10, 30.9$118.0 \mathrm{~mm} \mathrm{SL})$, Chocó, Andagoya, Quebrada tributary of río Condoto, 0506'03.9'” 7641'43.8'W. CAR 142 (9, 33.2-96.0), Chocó, Quebrada tributary of río Tutunendo, 0547'04.4”N 76³4'6.5'W. CAR 454 (1, 127.2 mm SL), Chocó, Comunidade Munguidó. Panama: MZUT 1591 Holotype (1, 134.4 mm SL), Darién, laguna Della Pita. CAS 66982 (6, 50.5-73.9 mm SL), Darién, Yaviza, 08 10 '18.4”N 7741'10.3”'W. NRM 35875 (3, 58.5-78.1 $\mathrm{mm}$ SL), Darién, Yaviza, tributary of río Tupisa, $08^{\circ} 11^{\prime} 59.9^{\prime} \mathrm{N}$ 7741'17.3”W. USNM 78641 (1, 107.8 mm SL), Dárien, río Yape, $08^{\circ} 06^{\prime} 58.7^{\prime} \mathrm{N}, 7^{\circ} 34^{\prime} 45.4$ 'W. Lebiasina floridablancaensis, Colombia. CAR 15-04-01 Holotype (1, 109.2 mm SL), Santander, 
Floridablanca Quebrada el Gaque, upper río Lebrija, $07^{\circ} 03^{\prime} 58.9^{\prime \prime} \mathrm{N}$ 7305'21.3”W. BMNH 1947.47.7.1.23-32 (9, 45.9-106.2 mm SL), Santander, Bucaramanga, $1000 \mathrm{~m}$ elev., río Magdalena drainage. CAR 15-04-23 (2, 105.1-117.9 mm SL), Santander, San Vicente de Chucuri Quebrada La Carbonera, tributary of río la Llana, 06 53'47.1'N 73²5'39.6"W. IAvH-P 4730 (2, 89.2- $106.3 \mathrm{~mm}$ SL), Santander, Girón, Quebrada el Palmar, tributary of río Del Oro, 0704'18.5'N 73¹0'32.5"W. CAR 260 (14, 131.2-46.0 mm SL), Santander, Lebrija, Vereda Lisboa, tributary of Sucio, río Lebrija drainage, $07^{\circ} 07^{\prime} 10.3$ "N $73^{\circ} 13$ '13.6”W. Lebiasina multimaculata, Colombia. BMNH 1910.7.11:167 Lectotype (1, $91.2 \mathrm{~mm} \mathrm{SL}$ ), Chocó, Condoto, río Condoto, $45 \mathrm{~m}$ elev., 0606'00”'N 7642'00”'W. CAR 15-04-34 (35, 21.6-48.7 mm SL), Chocó, Andagoya, Quebrada tributary of río San Juan, near the mouth río Condoto, $05^{\circ} 06^{\prime} 03.9^{\prime \prime N} 76^{\circ} 41^{\prime} 43.8^{\prime}$ 'W. CAR 138 (5, 52.9-103.7 mm SL), Chocó, Opogodó, río Opogodó, 5³'0”N 76³9'0"W. CAR 139 (13, 21.7-118.3 mm SL), Chocó, near the Tadó village, $05^{\circ} 15^{\prime} 25.2^{\prime \prime} \mathrm{N} 76^{\circ} 33^{\prime} 12.9^{\prime \prime W}$. CAR 451 (2, 110.9123.8 mm SL), Chocó, Quebrada Weguerál, río San Juan. Lebiasina ortegai, Colombia. CAR 445 (1, $55.8 \mathrm{~mm} \mathrm{SL})$, Cauca, Quebrada Gemagra, Popayán 1730 m elev., 02²7'03.5”N 76³7'12.1'W. CAR 145 (12, 66.3-137.3 mm SL), Valle del Cauca, Alcalá, creek tributary of río Barbas, 200 m near the río La Vieja, $04^{\circ} 40^{\prime} 46.3^{\prime \prime} \mathrm{N}$ 7547'33.7'W. CAR 157 Paratypes (4, 64.1-119.8 mm SL), Valle del Cauca, Florida, Quebrada tributary of río Cañas, Vereda el Tambor, $1100 \mathrm{~m}$ elev., 03¹8'50.7'N 76¹4'26.8'W. CAR 265 Paratypes (13 [not 7 as in Ardila-Rodríguez, 2008b:20], 34.7$114.8 \mathrm{~mm} \mathrm{SL}$ ), Valle del Cauca, tributary of río las Cañas, $200 \mathrm{~m}$ near the road between Florida and Miranda, $03^{\circ} 16^{\prime} 41.7$ 'N 76¹3'17.9'W. CAR 15-04-45 (1, 72.3 mm SL), Quindio, Quebrada el Broche, río Baragán drainage, in the road to Caicedonia, 04²0'07.2”N 7542’02.8'W. Lebiasina panamensis, Panama. USNM 16676 Lectotype (1, $65.9 \mathrm{~mm} \mathrm{SL})$, creek open into the Atlantic Ocean, channel area. USNM 16677 Paralectotype (1, $65.3 \mathrm{~mm}$ SL), Canal Zone, río Frijoles, 0908'24.9”N 7945'43”W. USNM 78656 (2, 120.1-128.3 mm SL), Agua Clara, río Trinidad, a large tributary of the río Chagres west of the route to the Channel, $09^{\circ} 18^{\prime} \mathrm{N} 79^{\circ} 47^{\prime} \mathrm{W}$. ANSP 126193 (4, 64.5-134.4 mm SL), $16 \mathrm{~km}$ de Cerro Azul, Pacific Ocean drainage, Cerro Azul, 09¹0’00'N 79²5’00”W. INHS 68116 (1, 54.3 mm SL), Colón, río Frijolito, bacia do río Chagres, Parque Nacional da Soberania, $09^{\circ} 10^{\prime} 11.1$ ' $\mathrm{N}$ 7946'54.6”W. INHS 68151 (5, 52.8-87.3 mm SL), Colón, Soberania State Park, río Frijolito, río Chagres drainage, 09¹0'11.1”N 7946'54.6”W. MCZ 45820 (1, 118.3 mm SL), channel area, near Gamboa, tributary of río Chagres, $09^{\circ} 07^{\prime} \mathrm{N}$ $79^{\circ} 42^{\prime}$ W. MCZ 80749 (11, 53.3-141.9 mm SL), creek in the Barro Colorado island channel area, 0909'47.9'N 7949'43.3"W. MNRJ 14541 (1, 139.1 mm SL; 1 c\&s, 100.0 mm SL), Comarca de San Blas, creek Bulebgandi, tributary of río Azúcar, $09^{\circ} 24^{\prime} 53.1$ '” 78॰38'20.0”W. Lebiasina taphorni, Venezuela. CAR 15-04-47 Holotype (ex-MCNG 19939) (1, 87.1 mm SL), Bolívar, Quebrada in the middle río Caura. CAR 15-04-48 Paratypes (ex-MCNG 19939) (6, 34.0-62.4 mm SL), Bolívar, Quebrada in the middle río Caura. CAR 15-04-15 (ex-MCNG 18817) (3, 106.6-123.7 mm SL), Bolívar, Cedeño, Guanajuja, creek upstream from a small fall, 0509'00”'N 6409'00'W. MCNG 18814 (5, 61.3- 123.0 mm SL; 1 c\&s, 67.9 mm SL, Bolívar, Cedeño, Guanajuja, creek upstream from a small fall, $05^{\circ} 09^{\prime} 00^{\prime \prime} \mathrm{N} 64^{\circ} 09^{\prime} 00^{\prime \prime} \mathrm{W}$. Lebiasina unitaeniata, Venezuela. BMNH 1988.2.16.1 Holotype (1, 100.4 mm SL), Guyana [Venezuela, Bolívar?]. AMNH 199331 (6, 103.4- 131.8 mm SL), Bolívar, Soropán-tepuí, Quebrada Sororopán tributary of the left margin of río Parupá, Alto Apon Wao drainage, $5600 \mathrm{~m}$ elev., $05^{\circ} 45^{\prime} \mathrm{N} 61^{\circ} 43^{\prime} \mathrm{W}$. CAR 485 (ex-MBUCV-V 22331) (7, 44.5- 98.4 mm SL), Bolívar, Gran Sabana, Quebrada Tarotá, río Apon Wao system. MZUSP 73090 (ex-MBUCV-V 29376) (10, 51.2-102.6 mm SL), Bolívar, Gran Sabana, Quebrada Tarotá, río Apon Wao system. USNM 163426 (5, 102.0-129.1 mm SL), Bolívar, Soropan-tepuí, 5600' elev., $05^{\circ} 45^{\prime} \mathrm{N} 61^{\circ} 43^{\prime} \mathrm{W}$. USNM 307215 (9, 50.6-110.4 mmSL), Bolívar, río Tarota, tributary of río Aponguao [=río Apon Wao]. Lebiasina uruyensis, Venezuela. AMNH 14263 (1, 82.1 mm SL), Bolívar, río Haicha, sopé do Auyán-tepui, $450 \mathrm{~m}$ elev., 0544'41”N 62²7'37'W. AMNH 59048 (20/52, 41.7-127.9 mm SL), Cerro Guaiquinima, creek into the forest, near the basecamp, $05^{\circ} 49^{\prime} 00^{\prime \prime} \mathrm{N} 63^{\circ} 40^{\prime} 00^{\prime \prime W}$. AMNH 59049 (4, 63.0-111.9 mm SL), Bolívar, tributary of the left margin of río Carapo, tributary of the right margin of río Paragua, 450550 m elev., $05^{\circ} 39^{\prime} \mathrm{N} 63^{\circ} 40^{\prime} \mathrm{W}$. CAR 15-04-14 (ex-MHNLS 787) (3, 87.4-90.4 mm SL), Bolívar, río Guayaraca, south of Auyan Tepuy, $980 \mathrm{~m}$ elev. $05^{\circ} 41^{\prime} \mathrm{N} 62^{\circ} 32^{\prime} \mathrm{W}$. CAR 456 (ex-MHNLS 14458) (4, 64.4- 81.4 mm SL), Bolívar, río Wareipita, Canaima State Park, Wareipa, 06 ${ }^{\circ} 00^{\prime} 32$ 'N 6246'52"W. MHNLS 789 Holotype (110.9 mm SL) and Paratypes (9, 96.6-118.0 mm SL), Bolívar, rio Guayaraca, ao sul de Auyán-tepui, $980 \mathrm{~m}$ elev., $05^{\circ} 41^{\prime} \mathrm{N}$ $62^{\circ} 32^{\prime} \mathrm{W}$. Lebiasina yuruaniensis. Venezuela. AMNH 1536 (1, 70.7 mm SL), Bolívar, Erkin creek, río Arabopo, 0447’ N 6052'W.AMNH 9662 (3, 82.3-118.5 mm SL), Bolívar, Arabupu, Roraima, $13 \mathrm{~km}$ southeast of Monte Roraima, $4200 \mathrm{~m}$ elev., 0506’N 6044'W, AUM 36649 (4, 27.7- 77.7 mm SL), Bolívar, tributary of río Waiparú, $\mathrm{km} \mathrm{77,} \mathrm{in} \mathrm{Waipan-} \mathrm{Tepuy,} \mathrm{río} \mathrm{Caroní}$ drainage, 04³0’ $\mathrm{N} 61^{\circ} 36^{\prime} \mathrm{W}$. AUM 36651 (2, 80.1- 83.9 mm SL), Bolívar, Fundo Cantarrana, río Ikabaru, tributary of río Caroní,

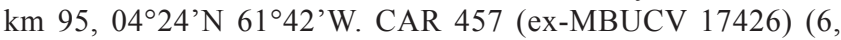
30.5-85.1 mm SL), Bolívar, Quebrada Cantarrana, $30 \mathrm{~km}$ north of Icabarú, Gran Sabana. CAR 477 (ex-MBUCV 17453) (5, 37.969.9 mm SL), Bolívar, Gran Sabana, Quebrada Aropán, between the río Anavaic and río Kamoirán. MBUCV 15286 (1, 126.2 mm SL), Bolívar, río Kakopauri between Santa Elena and San Ignacio de Yuruaní. MCNG 18992 (4, 41.5-69.3 mm SL), Bolívar, estrada El Dorado, Gran Sabana, km 149, 05³9'16.9"N 61²6’12.1"W. MCNG 19006 (7, 46.7-68.9 mm SL), Bolívar, Gran Sabana, 22 $\mathrm{km}$ south of Whao-Whao. MCNG 48089 (3, 24.5-70.1 mm SL), Bolívar, Heres, near the Salto Catedral, in Carucú-Maru, 4,6 km west of Santa Elena, 04³4'29.8”'N 61'12'58.8”W.

\section{Acknowledgements}

We are grateful to R. P. Vari for valuable comments and suggestions on the manuscript, and E. Baena for the photos and drawings in Fig. 2. We thank U. Barbosa and L. PyDaniel for the collection and donation of several specimens of the new species to INPA's fish collection. Authors were financially supported by FAPESP (fellowship 06/04161-5 ALN-F), www.biotasp.org.br (project 00/04300-9 OTO, "Diversidade de peixes de riachos e cabeceiras da Bacia do rio Ribeira de Iguape no Estado de São Paulo") and CNPq (productivity grant \#307464-2009-1 JZ).

\section{Literature Cited}

Ardila-Rodríguez, C. A. 1994. Lebiasina floridablancaensis, una nueva especie de pez para Colombia (Teleostei: Characiformes: Lebiasinidae). Revista Unimetro, 10 (19): 1-8. 
Ardila-Rodríguez, C. A. 1999. Lebiasina provenzanoi, una nueva especie de pez para Venezuela (Teleostei: Characiformes: Lebiasinidae). Revista Unimetro, 13 (5 \& 6): 1-10.

Ardila-Rodríguez, C. A. 2000. Lebiasina yuruaniensis, una nueva especie de pez para Venezuela (Teleostei: Characiformes: Lebiasinidae). Revista Unimetro, Separata Especial $\mathrm{N}^{\circ}$ s. 2, 3 (25 \& 26): 1-16.

Ardila Rodríguez, C. A. 2001. Lebiasina chucuriensis una nueva especie de pez para Colombia (Teleostei: Characiformes: Lebiasinidae). Revista Unimetro, 13 (27-28): 1-20.

Ardila-Rodríguez, C. A. 2002. Lebiasina nariñensis, una nueva especie de pez para Colombia (Teleostei: Characiformes, Lebiasinidae). Dahlia, 5: 11-18.

Ardila-Rodríguez, C. A. 2004. Lebiasina taphorni (Pisces: Characiformes, Lebiasinidae), una nueva especie. Dahlia, 7: 57-65.

Ardila-Rodríguez, C. A. 2008a. Lebiasina ortegai (Characiformes: Lebiasinidae), nueva especie, sistema del río Cauca, Colombia. Dahlia, 10: 17-25.

Ardila-Rodríguez, C. A. 2008b. Lebiasina colombia (Characiformes: Lebiasinidae), nueva especie cuenca del río Sinú, Colombia. Dahlia, 10: 27-32.

Ardila-Rodríguez, C. A. 2009. Lebiasina colombia (Ardila Rodriguez, 2008). Peces del Alto río Sinu, 1: 1-20.

Ardila-Rodríguez, C.A. 2010. Lebiasina chocoensis, una nueva especie de pez para Colombia (Teleostei: Characiformes: Lebiasinidae, Lebiasininae). Peces del Departamento del Chocó, 1: 1-20.

Dahl, G. 1971. Los Peces del norte de Colombia. Instituto de Desarrollo de Los Recursos Naturales Renovables (INDERENA), Bogotá, 391p.

Eigenmann, C. H. 1910. Catalogue of freshwaters fishes of tropical and south temperate America. Reports of Princeton University Expedition Patagonia, 1896-1899. Princeton, N. J., Princeton University, 3: 375-511.

Eigenmann, C. H. \& W. R. Allen. 1942. Fishes of western South America. I. The Intercordilleran and Amazonian lowlands of Peru. II. The high pampas of Peru, Bolivia and northern Chile. University of Kentucky, Lexington, 494p.

Fernández-Yépez, A. 1967. Primera contribución al conocimiento de los peces, con descripción de dos especies y una subespecie nuevas. Resultados zoológicos de la expedición de la Universidad Central de Venezuela. Acta Biologica Venezuelica, 5: 159-177.

Fernández-Yépez, A. 1972. Analisis Ictiológico del Complejo Hidrográfico (04) "río Yaracuy". Dirección de Obras Hidraúlicas, Ministerio de Obras Públicas, Republica de Venezuela, 25p.
Ferraris, C. J. 2007. Checklist of catfishes, recent and fossil (Osteichthyes: Siluriformes), and catalogue of siluriform primary types. Zootaxa, 1418: 1-628.

Fink, W. L. \& Weitzman, S. H. 1974. The so-called cheirodontin fishes of Central America with description of two new species (Pisces, Characidae). Smithsonian Contributions to Zoology, 172: 1-46.

Géry, J. 1977. Characoids of the World. Tropical Fish Hobbyist Publications, Neptune City, 672p.

Géry, J. \& Zarske A. 2002. Derhamia hoffmannorum gen. et sp. n a new pencil fish (Teleostei, Characiformes, Lebiasinidae), endemic from the Mazaruni River in Guyana. Zoologische Abhandlungen; Staatliches Museum für Tierkunde in Dresden, 52: 35-47.

Machado-Allison, A. 1974. Etapas del desarrollo del pez Piabucina pleurotaenia Regan 1903 (Characiformes: Lebiasinidae). Acta Biológica Venezoelana, 8: 579-622.

Menezes, N. A. \& S. H. Weitzman. 1990. Two new species of Mimagoniates (Teleostei: Characidae: Glandulocaudinae), their phylogeny and biogeography and a key to the gladulocaudin fishes of Brazil and Paraguay. Proceedings of the Biological Society of Washington, 102: 380-426.

Nelson, J. S. 2006. Fishes of the World. John Wiley and Sons, Inc. New York, 601p.

Netto-Ferreira, A. L. 2006. Relações filogenéticas dos gêneros de Lebiasinidae (Ostariophysi, Characiformes). Unpublished M.Sc. Dissertation, Universidade Federal do Rio de Janeiro, Rio de Janeiro, Brazil, 374p.

Netto-Ferreira, A. L. 2010. Revisão taxonômica e relações interespecíficas de Lebiasininae (Ostariophysi: Characiformes: Lebiasinidae). Unpublished Ph.D. Dissertation, Universidade de São Paulo, São Paulo, Brazil, 443p.

Taphorn, D. 1992. Characiform fishes of the Apure River drainage, Venezuela. BioLlania. UNELLEZ, Guanare, Venezuela, 537p.

Taylor, W. R. \& G. C. van Dyke. 1985. Revised procedures for staining and clearing small fishes and other vertebrates for bone and cartilage study. Cybium, 9: 107-119.

Weitzman, S. H. 1964. Osteology and relationships of South American characid fishes of subfamilies Lebiasinidae and Erythrinidae with special references to subtribe Nannostomina. Proceedings of the United States National Museum, 116: 127-170.

Weitzman, S. H. 1966. Review of South American characid fishes of subtribe Nannostomina. Proceedings of the United States National Museum, 119: 1-56.

Weitzman, M. \& S. H. Weitzman. 2003. Family Lebiasinidae. Pp. 241-250. In: Reis, R. E.; S. O. Kullander \& C. J. Ferraris, Jr. (eds.). Check List of the freshwater fishes of South and Central America, Porto Alegre, Edipucrs, 729p.

Submitted August 19, 2011 Accepted November 28, 2011 Published December 26, 2011 